Филозофски факултет - докторске студије Језик и књижевност

Нови Сад

jelenaperisic91@hotmail.com

\title{
УПОТРЕБА КНИЖЕВНОГ ТЕКСТА У НАСТАВИ (СРПСКОГ КАО СТРАНОГ) ЈЕЗИКА ${ }^{1}$
}

\begin{abstract}
АПСТРАКТ
У оквиру наставе страног језика важно место има повезивање садржаја из језика и књижевности, тачније употреба књижевних текстова на часовима намењеним усвајању језичких јединица. Како би се откриле пожељне особине књижевног текста за потребе наставе српског језика као страног и најбољи начини његове примене, најпре ће се представити ранија разматрања у вези са овом темом и захтеви које прописује Заједнички европски оквир за живе језике ${ }^{2}$, а затим дати предлози текстова и њихове обраде на различитим нивоима учења.
\end{abstract}

Кључне речи: настава страног језика, српски језик као страни, књижевни текст, Заједнички европски оквир.

1 Текст рада произашао је из семинарског рада на докторским студијама написаног за потребе предмета Естетика књижевности код доц. др Владимира Гвоздена.

2 Документ Савета Европе познат под називом Заједнички европски референтни оквир за живе језике (енг. Common European framework of Reference for Languages) чини данас заједничку базу за израду програма, уџбеника и проверу знања у настави страних језика у Европи. У њему се објашњава како се учи страни језик за потребе комуникације, указује на значај културног контекста у учењу страних језика и дефинишу нивои компетенције (А1, А2, Б1, Б2, Ц1, Ц2) који омогућавају праћење постигнућа у учењу у различитим фазама живота појединаца на исти начин у целој Европи. Као радна верзија постојао је 1995. године, a 1997. Савет Европе га је званично усвојио и објавио на интернету. Верзија на енглеском и француском појавила се 2001, а године 2003. превод на српски језик објавило је Министарство просвјете и науке Републике Црне Горе (Ђоровић 2011: 822). 


\title{
THE USE OF A LITERARY TEXT IN TEACHING (SERBIAN AS A FOREIGN) LANGUAGE
}

\begin{abstract}
In the context of foreign language teaching, the connection between the content of language and literature, specifically the use of literary texts in classes that focus on the adaptation of the language units, is very important. In order to detect the desirable characteristics of the literary text for teaching Serbian as a foreign language and the best ways of its implementation, previous considerations regarding this topic will be presented. Next, the paper lists the requirements approved by the Common European Framework of Reference for Languages, and then gives suggestions of texts and their processing at different levels of learning.
\end{abstract}

Key words: foreign language teaching, Serbian as a foreign language, literary text, Common European Framework of Reference for Languages.

\section{1. УВОД}

Предмет овог рада је анализа употребљивости књижевног текста у настави страног језика, а све то у циљу откривања пожељних особина књижевног текста и најбољих начина његове примене у настави српског језика као страног. Како би се остварио циљ, потребно је испунити задатке у виду упознавања са значајем повезивања садржаја из језика и књижевности и значајем употребе књижевних текстова у настави језика, представљања захтева које прописује Заједнички европски оквир за живе језике питању текстови који се користе у настави страних језика, направити преглед ранијих разматрања у вези са овом темом, да би се потом изложили начини на које се текст може употребити и дали предлози текстова из домаће књижевности, као и предлози њихове употребе у настави српског језика као страног.

Теоријски оквир се заснива на књигама и радовима домаћих и страних аутора из области наставе матерњег језика, наставе страног језика уопште и српског као страног језика, који уједно представљају и примарни корпус. Као секундарни корпус биће коришћени поетски и прозни текстови српских песника и писаца. Извор података о тематским целинама и садржајима ни-

3 У даљем тексту ЗЕО. 
воа чине уџбеници Научимо српски 1 и Научимо српски 2, ${ }^{4}$ који се користе на курсевима у оквиру Центра за српски језик као страни на Филозофском факултету у Новом Саду.

\section{1. Значај повезивања садржаја из језика и књижевности и употребе књижевног текста у настави страних језика}

У настави матерњег језика (а исто тако и страног), неопходна је повезаност садржаја из језика и књижевности. У прилог томе говори став Павла Илића да у неминовном повезивању наставе језика и књижевности користи имају обе области, али и култура усменог и писменог изражавања jep је, како аутор сматра, настава књижевности у анализи организације језичке грађе уметничког текста нашла поуздан ослонац за откривање његових естетских вредности и суђење о њима. Почетно мотивисање за учење нове језичке појаве најснажније је онда кад се тој појави приступи преко њене реализације, која је управо у уметничком тексту. Тако се језичка појава која hе се изучавати најпре уочава у њеној функцији, нпр. облик вокатива у узвичним реченицама, аориста у динамичним ситуацијама, супротан однос међу зависним реченицама у контрастним песничким сликама (Илић 2006: 538). Илић преноси запажање Зорана Константиновића да се све књижевнонаучне методолошке оријентације које у средиште свога изучавања стављају књижевно дело, које му приступају изнутра, неминовно баве језиком дела и да су основне оријентације феноменолошког изучавања књижевног дела усмерене на његов језик и естетски предмет њиме створен (Илић 2006: 530 према Константиновић 1969: 45-64).

Љиљана Петровачки истиче да је језик средство књижевно-уметничког изражавања и тако објашњава оправданост повезивања садржаја из језика и књижевности. По њеном мишљењу, у школским интерпретацијама књижевних дела обраћа се велика пажња на језик и стил писца, на стилска

4 Као резултат искустава у раду у Летњој школи и Центру настали су уџбеници Научимо српски 1 (2004. године; најновије издање 2014. године) и Научимо српски 2 (2007. године). Сваки од уџбеника прате радна свеска и це-де ромови са вежбама слушања. Прва књига оквирно обухвата нивое А1 и А2 (по пет лекција), друга Б1 и Б2 (такође по пет лекција за сваки ниво). Структура књига, одабир и представљање језичке грађе, као и њихов обим, повезани су са сврхом и циљевима учења. Грађа је организована тематски. У свакој лекцији постоји једно или више тематских поља која чине срж те лекције. У оквиру сваког поља учи се основна лексика, граматичке категорије значајне за то семантичко поље, развијају се све језичке вештине (Суботић-Бјелаковић 2007: 173-183). 
средства којима су остварени одређени естетски ефекти, а за то је потребно лингвистичко знање (Петровачки 2008: 173).

„У настави језика нужно је посматрати језичке појаве у животним и језичким околностима које су условиле њихово значење, па ученике ваља упутити на погодне текстове и говорне ситуације у којима се одређена језичка појава природно јавља и испољава“" (Петровачки-Штасни 2008: 29).

Зорица Несторовић наводи предности удруживања садржаја из српске књижевности, културне историје и граматике и, у вези са значајем повезивања садржаја из језика и књижевности, каже да:

„Нераскидивост веза језика и књижевности постаје, понекад готово парадоксално, израженија у тренутку када се сусретнемо са остварењима великих писаца који нису писали на нашем матерњем језику“ (Несторовић 2011: 207).

Ауторка говори о вези језика и књижевности у настави страног језика, док раније наведени аутори истичу значај ове везе у оквиру учења матерњег језика. То што и једни и други повезаност садржаја из ова два домена сматрају неопходном, доказ је да се морају комбиновати лингвистички и књижевни садржаји, без обзира на то да ли се ради о матерњем или страном језику.

У вези са значајем примене књижевног текста у настави матерњег језика Павле Илић каже да се, због лепоте којом уметнички текст мотивише ученике, учење језика све више везује за књижевни текст и онда када су часови намењени језику. Од текста се полази да се ученици мотивишу за учење језичких појава, да се нађу примери на којима ће се оне уочавати, анализирати, закључивати о њиховим значењима и облицима на којима ће стечена знања увежбавати и проширивати (Илић 2006: 532). Љиљана Петровачки и Гордана Штасни истичу да уметничка доживљавања чине граматичко градиво конкретнијим, лакшим и применљивијим. Кад ученицима постане приступачна стилска (изражајна, експресивна) функција језичке појаве, прихватају је као стваралачки поступак, што доприноси бољем писменом и усменом изражавању, али и успешној анализи књижевних текстова (Петровачки-Штасни 2008: 30).

О употреби књижевног текста у настави страних језика и њеном значају говори Пени Ур (Реnny Ur) у књизи A Course in Language Teaching: Practice and Theory (1997). Она наводи предности и мане укључивања књижевности створене на језику који се учи у било који курс ком је 
главни циљ усвајање знања из самог језика. ${ }^{5}$ Након сагледаних добрих и потенцијално лоших одлика, ауторка износи лични став да је присталица укључивања књижевности у курсеве, не само као богатог извора језика, већ и због естетских вредности које доприносе мотивацији и уживању. Проблеми дужине, тежине и непознатог садржаја могу се решити пажљивим одабиром текстова или коришћењем одломака. Уколико се процени да је сачувано довољно литерарне вредности оригинала и да ће то бити корисно за студенте, могу се користити и упрошћене верзије (Ur 1997: 201). Домаћи културни садржај, по њеном мишљењу, обезбеђује теме за дискусију која је блиска, интересантна и мотивишућа. Култура и књижевност језика који се учи, као и култура других земаља, веома је важна за образовање студената (Ur 1997: 208).

\section{2. ЗАЈЕДНИЧКИ ЕВРОПСКИ ОКВИР - ЗАХТЕВИ У ВЕЗИ СА ОСОБИНАМА ТЕКСТА}

Према 3EO, у основне карактеристике текста спадају: лингвистичка сложеност, врста текста, структура дискурса, дужина и релевантност текста за ученике. Што се сложености тиче, сложена синтакса тражи додатну пажњу (нпр. дуге реченице које садрже бројне зависне реченице, вишеструке негације, неконтинуиране делове, употребу анафора и показних заменица без јасних антецедената). С друге стране, превелико синтаксичко поједностављивање аутентичних текстова може довести до повећања нивоа тежине. Када је у питању врста текста, познавање жанра и домена помаже

5 Назначене предности су следеће: књижевност може бити пријатна за читање; обезбеђује примере различитих стилова писања и репрезентује различите аутентичне употребе језика; књижевни текст је добра база за ширење вокабулара; развија вештину читања; може обезбедити одличну полазну тачку за дискусију или писање; укључује емоције (осећања) као што је интелект који појачава мотивацију и доприноси развоју личности; део је културе језика који се учи и користан за опште образовање; подржава емпатију, критичко и креативно размишљање; доприноси знању о свету; подиже свест о различитим животним ситуацијама и конфликтима. Недостаци или, боље речено, могући проблеми у вези са књижевним садржајима били би следећи: већина дела је написана језиком који може бити тежак за разумевање онима који уче страни језик; могу се користити упрошћене верзије али су оне само осиромашена представа оригинала; многи књижевни текстови су дуги и одузимају доста времена приликом учења; култура језика који се учи и на којој је књижевност базирана страна је ученицима и може им бити тешко да се повежу; коришћењем текстова као основа за учење језика ученицима се може покварити уживање у текстовима као књижевним делима; студенти науке и технологије могу књижевност сматрати ирелевантном за своје потребе (Ur 1997: 200). 
ученику да разуме и предвиди структуру и садржај текста. Ако се посматра природа текста, конкретан опис, инструкција или нарација вероватно ће бити мање захтевни од апстрактне аргументације и објашњења. Што се тиче структуре дискурса, текстуална кохерентност и јасна организација, више експлицитна него имплицитна природа информације, одсуство конфликтних и неочекиваних информација доприносе смањењу сложености обраде информација. У погледу дужине, краћи текст је, генерално гледано, мање захтеван од дужег, написаног на исту тему (дужи текст захтева комплекснију обраду, додатно је оптерећење за меморију, јавља се ризик од умора и непажње). Ипак, уколико дужи текст садржи довољну дозу редундандности и није збијен, може бити лакши од краћег збијеног који садржи исте информације. Битан је и вокабулар који текст садржи. Вокабулар који се ретко среће повећаће тежину текста, али ће текст који садржи специфичан вокабулар и везан за познату тему бити мање захтеван за стручњака на том пољу од текста који садржи вокабулар опште употребе (ЗЕО 2003: 179-180).

Постоји више могућности за бирање лексике која ће ући у текстове: да се изаберу кључне речи и изрази у тематским областима неопходним за остваривање комуникативних задатака релевантних за ученика, или оних који одражавају културне разлике или веровање друштвене групе чији се језик учи; да се следе лексичко-синтаксички принципи и бирају најфреквентније речи у великим општим корпусима или оним који су ограничени на тематске области; да се одаберу аутентични текстови и да се уче/ семантизују све речи које садрже; да се не планира унапред развој вокабулара, већ препусти да се развија као одговор на ученикове захтеве када обавља комуникативне задатке (ЗЕО 2003: 164).

Посвећена је пажња и задацима који прате текстове. С тим у вези, врста одговора који се захтевају у задатку који прати текст може неутралисати сложеност текста, тако што ће се прилагодити компетенцијама и карактеристикама ученика. Дизајн задатка може зависити и од тога да ли му је циљ развијање вештине разумевања или провера разумевања. Задатак разумевања може захтевати опште или селективно разумевање, или разумевање битних детаља. Неки се могу односити на захтев да онај ко чита покаже разумевање јасно саопштених информација у тексту, док други могу бити концентрисани на вештину закључивања. Задатак може бити сумаран (на основу комплетног текста) или се односити на мање јединице и тако мање оптеретити памћење. Одговор који се захтева може бити невербалан и вербалан у усменом и писменом облику. Уколико је у писменом облику, може у себи садржати идентификацију и репродукцију информација из 
текста у одређену сврху или захтев да ученик доврши или произведе нови текст (ЗЕО 2003: 179-181).

Поставља се питање какву улогу треба да имају текстови у учењу и настави страног језика. У вези са тим предвиђају се начини на које се може очекивати да ученици уче на основу текстова: 1) на основу простог излагања текстовима; 2) на основу простог излагања, али уз гаранцију да је нови наставни материјал разумљив, извлачење закључака на основу вербалног контекста, визуелне подршке, итд; 3) излагањем, уз омогућавање и праћење разумевања питањима и одговорима на J26, вишеструким избором, слагањем слика, итд.; 4) исто као претходно наведено, али уз неку од додатних активности попут тестова разумевања на J1, објашњења на J1, објашњења на J2, систематског превођења текста на J1 од стране ученика, активности које претходе читању (ЗЕО 2003: 159).

\section{3. ПРЕГЛЕД РАНИЈИХ РАЗМАТРАЊА}

У овом поглављу ће бити представљена истраживања примене текста у настави српског језика као страног, као и екстензивног читања. Изузетак представља оглед хрватских ауторки спроведен на материјалу енглеског и италијанског језика, који је за нашу тему користан јер се односи на обраду бајке у настави страног језика.

По мишљењу Јелене Марковић, екстензивно читање представља приступ настави и учењу читања у коме ученици читају велику количину материјала (Marković 2005: 492). Као најважније ефекте оваквог читања ауторка издваја: напредак у читању (увећање броја речи које се аутоматски препознају) и писању, усвајање нових речи, напредак у знању граматике и спелинга, обогаћивање општих знања о свету (Marković 2005: 494). Са друге стране, постоји интензивно читање које се у настави страних језика често користи у анализи језика текста, при чему се усвајају нове лексичке или граматичке јединице (Marković 2005: 492). На основу претходно реченог, може се претпоставити да је, у случају српског језика као страног, екстензивно читање боље за усвајање културе и ширење лексичког фонда, а интензивно за усвајање и увежбавање језичких јединица, посебно на нижим нивоима учења страног језика. Интензивно читање у оквиру курсева страних језика одобравају и аутори књиге Learning Vocabulary in Another Language?.

6 J1 - матерњи језик, J2 - језик који се учи.

7 Интензивно читање и директно учење не препоручују се у настави матерњег језика јер 
Ирина Иванова се бавила усвајањем културних образаца кроз текстове приликом учења српског језика као страног и открила да за студенте који се упознају са књижевним делима на страном језику постоји проблем адекватног разумевања, нарочито ако су догађаји временски и просторно удаљени од читаоца (Иванова 2011: 113). Решење тог проблема ауторка види у приказивању свакидашњег живота једног народа у облику система који би узимао у обзир време, простор, идеологију, где би требало одредити место сваком елементу који је важан за културу тог народа. Номинација таквих елемената често спада у категорију речи које немају потпуни еквивалент у другом језику (у овом случају руском, јер је ауторка радила са студентима којима је руски матерњи језик), дакле у врсту безеквивалентне лексике (Иванова 2011: 113-114). За студенте који тек проучавају јужнословенске језике и слабо су упознати с детаљима свакидашњег живота тих народа у прошлости, ови појмови остају нејасни (Иванова 2011: 114). Иванова се у раду зауставила само на неколико примера речи и појмова који захтевају коментар, а односе се на лексику из Андрићеве приповетке Пут Алије Ђерзелеза. Према њеним речима, прича која се односи на сваки од појмова израста у мини-есеј који укључује и многе друге појмове на којима се базира семиотички систем, тако да студенти могу да се упознају са читавом разгранатом структуром одређене области живота једног народа, што би омогућило разумевање књижевног дела (Иванова 2011: 121). О истом проблему Зорица Несторовић каже:

„У великом броју случајева преко језичке грађе до нас долази свест о особинама култура унутар којих она постоји. О духу времена, као и о духу неке културе, народа, појединачних писаца, често много тога, готово и несвесно, усвојимо док покушавамо да освојимо што је могуће више знања о језику који учимо као страни“" (Несторовић 2011: 207).

Објашњења која спомиње Иванова у текст би могла бити укључена у виду глоса/напомена, о којима се говори у поглављу Vocabulary and reading and writing у оквиру књиге Learning Vocabulary in Another Language. ${ }^{8}$

захтевају много времена и много је речи, али ово се не може дословно односити на учење страног језика из два разлога. Као прво, постоји разлика у високој и ниској фреквентности. Изворни говорници крећу у школу када већ знају око 5000 речи које укључују високофреквентне речи, нова лексика се односи на нискофреквентне речи. Неизворни говорници, у сваком случају, морају да науче и високофреквентне речи па је директно учење оправдано. Друго, директно учење може допринети ненамерном, успутном учењу појединих речи и повећати свесност ученика о појединим речима тако да их примете када их сусретну током читања (I.S.P. Nation - Victoria University of Wellington 2001: 255).

8 Објашњење/глоса (енг. gloss) је кратка и јасна дефиниција или синоним на J1 или J2, која је 
3. Несторовић даје примере вишеструке примене садржаја из књижевности у настави српског језика као страног. ${ }^{9}$ Истиче да конзистентност односа језика и књижевности која на њему настаје постаје наглашенија у тренутку када је полазник курса за учење српског као страног већ савладао основни (почетни) ниво познавања језика, па се може рећи да он креће да учи језик у оном тренутку када, поред утврђеног минималног фонда речи, самостално покуша да разуме неке друге речи и да им нађе еквиваленте у свом матерњем језику. Тако успостављене сличности и разлике могу га додатно мотивисати да, упознајући граматичка правила, синтаксичке склопове, фонолошке обрасце, облике писма и фразеологизме, упознаје дух језика у свеукупном богатству његове примене, у лепоти и изражајности његовог значења (Несторовић 2011: 208). Група фактора који утичу на могућности примене садржаја из књижевности у настави српског као страног језика обухвата оне чиниоце који су условљени природом наставног програма, тачније његовим доменима и умећима које полазник треба да савлада у оквиру стицања знања српског језика као страног. Полазећи управо од домена, лектор обликује наставну јединицу тако да непрестано има на уму који садржаји из књижевности могу одговорити захтеву савладавања одређеног умећа. Кратки одломци из књижевног дела могу одлично послужити различитим врстама провере способности као што су: формулисање кратких реченица или кратког текста у вези са датим текстом (предлошком), постављање питања, давање одговора, описивање ситуације,

обогаћена текстом. Некада су речи у тексту маркиране како би се показало да су објашњене. Овакве напомене имају одређене одлике. Прво, ученицима може бити тешко да читају без њих, што значи да олакшавају читање непоједностављених и неадаптираних текстова. Друго, представљају прецизирање значења речи које се можда не би адекватно претпоставило на основу контекста. Треће, обезбеђују минималне прекиде тока читања, посебно уколико се јављају близу речи на коју се односе, а речник би захтевао много више времена. Четврто, скрећу пажњу на циљане речи и подстичу учење. Истраживања везана за објашњења показују да она доприносе учењу вокабулара, као и разумевању. Најбоље је поставити их на маргинама и могу бити и на J1 и на J2 све док их је лако разумети, напомене на J1 имају бољи ефекат ако се ради о учењу вокабулара, али се не разликују од оних на J2 када је у питању разумевање. Због тога што је учење уз помоћ објашњења углавном успутно (фокус је обично на разумевању текста), ово није савршен вид учења. У сваком случају, помаже ученицима у процесу постепеног јачања и богаћења лексичког фонда (I.S.P. Nation - Victoria University of Wellington 2001: 280-285).

9 Први пример који ауторка даје у раду је песма Васка Попе Свети Сава и обухвата предности удруживања садржаја из српске књижевности, културне историје, историје и граматике. Други пример, одломак из Нечисте крви у ком је описан портрет Софке, представља погодности употребе прозног текста у анализи и вежбама при учењу придева и прилога и уочавању њихових сличности и разлика. 
издвајање кључних речи, препричавање и слично (Несторовић 2011: 208). „Текстови могу бити драгоцени текстови-огледи у испитивању степена умешности савладавања умећа из домена стила, семантике, па и граматике“ (Несторовић 2011: 209).

Сава Анђелковић обраћа пажњу на учење текста за сцену и резултате у савладавању српског као страног језика. Сматра да је, када студенти науче напамет текстове песама или једног комада који траје сат и по или два сата, извесно да је и њихово свеукупно владање језиком много боље (Анђелковић 2011: 339). Изненађујућу чињеницу да студенти који непуне две године уче страни језик успевају да науче толике количине текста за сценско извођење објашњава тиме да се не ради само о учењу текста напамет, већ и о емотивној подлози при којој се тај текст изговара. Овакво памћење са емоционалном конотацијом омогућује брже усвајање одређеног текста, а говорнику пружа сигурност приликом конструкције нових реченица у говорном језику. Језик му постаје средство комуникације у којој се користи ново стечено знање, које му нуде српски песници и драмски писци (Анђелковић 2011: 340). Принцип рада у Атељеу ${ }^{10}$ ближи је индуктивном учењу када студенти откривају правила самом употребом језика, него дедуктивном, путем самих правила. Грешке се бележе и упућују сваком студенту на крају часа (Анђелковић 2011: 340). Рад са студентима који почиње од анализе текстова, преко припреме представа, а завршава се извођењем позоришне представе, показао је да позоришна представа може бити инструмент очигледне наставе. Поред књижевног дела неког аутора, студенти се упознају са проблемима везаним за поезију и њено сценско адаптирање, док током практичног рада на драмском тексту или његовој адаптацији схватају двојни карактер драме, односно разлике између драмског текста и представе тог истог текста на сцени. Студенти добијају одређена знања из језика и културе, али извлаче корист и на индивидуалном плану (Анђелковић 2011: 340). Учење текстова напамет тема је којом се бавила и Пени Уp (Ur 1997: 95), која предлаже начине варијације текста који се могу, али и не морају, комбиновати са учењем напамет. ${ }^{11}$

10 Рад је настао на основу искуства стеченог током рада у „Атеље театру на српскохрватском језику“ на катедри за славистику Универзитета Париз IV-Сорбона.

11 Креирање новог текста на сличну тему (писање након читања); предлагање другачијих начина на које ликови могу изразити исте мисли и улоге и образлагање разлике коју уносе те измене; презентовање оригиналног текста на другачији начин као нпр. запис у дневнику, реконструкција дијалога (Ur 1997: 95). 
Обрадом бајке у настави страних језика бавиле су се Тришња Пејић и Магдалена Нигојевић које сматрају да се увођењем бајки у наставу даје нови смисао језику који се подучава и усваја. У настави страних језика бајка је погодна за развијање свих језичких вештина (слушања, говорења, читања и писања), за увођење и увежбавање вокабулара и граматике, те за развијање способности критичког мишљења (Pejić-Nigojević 2004: 147). Бајке су баштина целог света, настале су усменим предањем и стога их је лакше разумети него друге књижевне врсте. Јединствене су, не само као књижевни облик, него и као уметничка дела јер су одраз друштва, културе и моралних вредности. Сваки појединац ће у различитим тренуцима свог живота доживети бајку на другачији начин. Свако ново знање се надовезује на претходно и то би требало искористити и у настави страних језика. Увођењем бајке у наставу страног језика преносимо познате појмове, ликове и приче. Препричавањем дајемо нови смисао језику који усвајамо, тај језик нам постаје ближи јер је оно о чему говоримо дубоко укорењено у нашој свести. Бајке тако истовремено служе и за учење језика и за стварање нових слика о свету (Pejić-Nigojević 2004: 147). Ауторке наводе особине које бајку чине изразито прикладном за учење страног језика: строго утврђен хронолошки ред, понављање речи и реченица, предвидљивост догађања, једноставност структуре, конкретан вокабулар и природни реченични ритам и интонација (Pejić-Nigojević 2004: 147). У раду дају примере бајки у учењу италијанског и енглеског језика. Код обраде бајке на италијанском језику, текст се користи за: увежбавање употребе прошлих времена, творбу речи, усвајање и употребу новог вокабулара; избор придева који одговарају појединим ликовима; склапање правилног редоследа делова приче; увежбавање глаголских времена и њихове употребе; творбу речи, суфиксе и њихова значења; проналажење израза који садрже називе боја и проналажење таквих израза у реченицама; посматрање текста са културолошког аспекта приликом чега се усвајају универзалне вредности (Реjić-Nigojević 2004: 148-149). Када је у питању енглески језик, даје се предлог за: осавремењивање бајке тако што студенти добијају задатак да традиционалне појмове замене модерним; вежбање прошлих времена тако што добију текст са празнинама и глаголе у инфинитиву а потребно је да напишу у прошлом времену, након чега слушају бајку и проверавају; мењање краја бајке (Рејić-Nigojević 2004: 149-151). Све ове идеје могу бити корисне за конструисање материјала који ће се користити у настави српског као страног језика. 


\section{3А ШТА СЕ СВЕ КЫИЖЕВНИ ТЕКСТ МОЖЕ ИСКОРИСТИТИ У НАСТАВИ ЈЕЗИКА?}

На основу ранијих истраживања може се видети за шта је све погодан књижевни текст у настави језика. Без обзира на то да ли је реч о поетском, прозном или драмском тексту, користан је за проширивање вокабулара ${ }^{12}$. Потребно га је само пажљиво одабрати у складу са циљевима часа и темом која се у том тренутку обрађује.

Сваки уметнички текст садржи стилске фигуре и погодан је за њихово усвајање. С друге стране, поред тога што су добар материјал за усвајање лексике, одређене стилске фигуре попут асонанце (нпр. А небо је тако мутно, / Као око исплакано. - Ј. Ј. Змај, Булићи увеоци ХХII) и алитерације (нпр. Прохладни пада мрак; / Врх хриди црне / Трне / Задюи румени зрак. - А. Шантић, Вече на шкољу) помажу приликом увежбавања изговора појединих гласова и њихових група.

Текстови се могу користити и као материјал за усвајање градива из граматике. ${ }^{13}$ Бајка је подесна за увежбавање прошлих времена и развијање свести о употреби различитих глаголских облика. Обрадом одломака из романа, приповетке и сличних прозних дела усвајају се синтаксички и фонолошки обрасци, граматичка правила, уочавају односи и разлике између различитих врста речи. И поезија је подесна за граматичка вежбања, посебно када су у питању различите врсте речи или смена глаголских времена, као и напоредни односи међу реченицама.

Књижевни текстови су веома употребљиви као полазни материјал за усвајање свих језичких вештина. Обрадом бајке развијају се све језичке вештине, погодна је за стварање нових текстова, па се тако може дати задатак у ком се захтева осавремењивање бајке или мењање њеног краја.

12 Истраживања везана за читање на матерњем језику показују да су познавање вокабулара и разумевање прочитаног текста узајамно блиско повезани - познавање вокабулара помаже читању, а читање доприноси ширењу вокабулара. Исто важи и за страни језик. Познавање вокабулара је знак ширине читања, познавања света и вештине разумевања прочитаног (I.S.P. Nation - Victoria University of Wellington 2001: 236).

13 И аутентичне текстове је могуће користити као контролисане/прилагођене, с тим што се мора водити рачуна о томе како се презентују ученицима. Овакви текстови нису специјално конструисани за учење језика, па језик није контролисан. Могуће је да садрже доста различитих граматичких структура и појединачне граматичке јединице вероватно неће бити укључене на исти начин као у контролисан текст, што имплицира да ће аутентичан текст бити кориснији за скретање пажње на опсег различитих граматичких јединица него на појединачне циљане структуре (Scrivener 2005: 282). 
И остали прозни текстови су посебно прикладни за развијање вештина писања и говорења јер пружају прилику за препричавање или конструисање новог текста.

Бајка је захвална за развијање способности критичког мишљења, усвајање универзалних вредности и вредности нације у којој је настала, али и за навикавање на фикцију, која је саставни део доживљаја живота и света. За усвајање културних образаца могу послужити и остале врсте прозних текстова, али и поетски и драмски. Такође, сви ови текстови после анализе и обраде на часу могу подстаћи полазнике курсева на екстензивно читање на вишим нивоима учења (заинтересују се за опус једног песника, након одломка пожеле да прочитају читаво прозно или драмско дело).

Постоје књижевни жанрови који би, захваљујући својим особинама, такође били корисни у настави језика, а нису споменути у консултованој литератури. То су, на пример, (ауто)биографија, путопис или записи из дневника. Биографија се може користити приликом вежбања везаних за прошло време. Такође, добар је мотивациони текст за конструисање новог текста и јачање кометенције писања (нпр. у оквиру девете лекције на А2 нивоу дати студентима задатак да на основу нечије биографије напишу интервју са том личношћу). Записи из дневника се могу уклопити у различите тематске целине, у зависности од садржаја белешке. О предностима путописног текста биће више речи у наредном одељку.

\section{5. ПРЕДЛОГ ТЕКСТОВА И ЊИХОВЕ ОБРАДЕ}

У наставку ће бити предложено неколико прозних текстова, као и задаци који би их могли пратити и тако допринети ефикаснијем усвајању српског језика као страног на различитим нивоима учења. У питању су кратка народна бајка и одломци из путописа.

\section{1. Прилог 1: Тамни вилајет - народна бајка}

Реч је о краткој народној бајци. Текст је добар за увежбавање прошлих времена, аориста ${ }^{14}$ и перфекта. У вези са тим, студенти могу добити задатак да издвоје све глаголе у аористу и перфекту, напишу њихове форме у инфинитиву и одреде им вид. Тако би индуктивним

14 Тек на вишим нивоима јер, према садржају консултованих уџбеника, обрада аориста није планирана на почетном, вишем почетном, средњем и вишем средњем нивоу. 
путем закључили од каквих се глагола гради аорист (само од свршених), а од каквих перфекат. На основу оваквог текста стиче се и свест о употреби различитих глаголских времена: перфекта, аориста, али и презента за исказивање прошлих радњи.

На вишим нивоима, текст је погодан као мотивација за учење глаголских прилога, прошлог и садашњег. Студентима се може поставити задатак да ове конструкције трансформишу у реченице и тако закључе шта се заправо исказује глаголским прилозима (нпр: (...) дошавши с војском на крај света (...) $\rightarrow$ када је дошао са војском на крај света; (...) не знајући како ће се натраг вратити (...) $\rightarrow$ пошто нису знали како ће се натраг вратити (...)).

Текст садржи односне реченице (субјекатске и речнице са везницима који и $и т о)$, те се може искористити као полазни текст за учење ових граматичких конструкција.

У питању је нетипична бајка (на прелазу између бајке и легенде), крај није срећан. У том погледу, студенти могу добити задатак да промене крај бајке. На тај начин се јачају компетенције везане за вештину писања.

Пошто се ради о народној бајци која припада старијим временима, захвална је и за поступак модернизације. Може се дати задатак да одређене појмове замене модернијим и пронађу савремене еквиваленте за нпр. вилајет, кобиле, ждребад, драго камење. Тако се јачају вештине писања, говорења, а подстиче се и на размишљање. Такође, добра је основа за дискусију о систему вредности некада и сада. Дискутовати се може и о поуци ове бајке, чиме би се развијала вештина говорења и закључивања.

Додатак у виду напомена (глоса) допринео би разумевању културно специфичних појмова. Ако би се текст користио на нижим нивоима, потребно га је упростити и поједине речи и конструкције заменити једноставнијим. На пример, за потребе коришћења на А2 нивоу (студенти на овом нивоу раде перфекат, али не и аорист; непознате су им безличне реченице, глаголски прилози, презент који се користи за исказивање прошлих радњи; поједине речи, синтагме и типови зависних реченица такође би били тешки за разумевање па и њих треба заменити) упрошћена верзија могла би изгледати овако:

Ђуди приповедају да је неки цуар, када је дошао с војском на крај света, пошао у тамни вилајет где се никад ништа не види. Нису знали како ће се вратити назад. Зато су онде оставили ждребад од кобила и требало је да их кобиле касније изведу из оне помрчине. Када су ушли у тамни вилајет и иили по юему, под ногама су осећали некакво ситно камење. Из мрака је 
нешто повикало: „Онај ко овога камења понесе кајаће се, а онај ко не понесе кајаће се." Неки су помислили: „Кад ћу се кајати, зашто да га носим?“ А неки: „Желим бар један да понесем. “Када су се вратили из таме на свет, видели су да је све било драго камење. Онда су се они који нису понели покајали зато што нису, а они који су понели - зато што нису понели више.

По тематици се може уклопити у десету лекцију у уџбенику Научимо српски 2 на Б2 нивоу где се говори о обичајима и веровањима. Упрошћена верзија би на А2 нивоу могла да послужи као материјал за вежбање после осме лекције, након обраде футура.

\section{2. Прилог 2: Јован Дучић, Градови и химере - путопис (одломак)}

Понуђена су два различита одломка текста Писма из Франиуске: А) се односи на опис пролећа у Паризу, Б) на опис Сене.

А) Реч је о дескрипцији, текст је богат описним придевима, у различитим степенима поређења. Стога је погодан за увежбавање придева на свим нивоима учења.

Доминирају облици перфекта па се текст може употребити на вишем почетном нивоу учења да илуструје када се користи свршени, а када несвршени вид код овог глаголског облика. На исти начин се може обрадити и презент. Студенти могу добити задатак да препишу текст тако што ће све глаголе из перфекта пребацити у презент, или обрнуто.

Текст садржи неколико узрочних реченица са везницима јер и зато што, те је погодан као полазни текст на часу предвиђеном за ове реченице, или за увежбавање усвојеног градива.

На овом примеру студенти могу уочити супротни однос међу независним реченицама и касније то правилно применити у комуникацији.

Б) У читавом тексту, а посебно на почетку, имамо придеве који означавају одређену димензију (тесне, широки, огромни, велики). То је добар материјал за, на пример, задатак на А2 нивоу који може садржати захтев да се одреди основни облик оваквих придева, а онда пронађу антоними и/ или именице које им одговарају (ширина, величина).

Занимљив задатак био би и да се у тексту пронађу антонимски парови међу придевима, прилозима и глаголима, будући да су у овом одломку заступљени контрасти, како на лексичком, тако и на синтаксичком нивоу.

У тексту се смењују различита глаголска времена па може послужити као пример њиховог комбиновања. 
Од стилских фигура присутни су епитети, контрасти, метафоре. Било би добро посветити пажњу метафоричним изразима артерија града и главни нерв живота, дискутовати о значењу и сл.

Ако се посматрају тематски, ова два одломка (у оригиналу) се могу укључити у девету лекцију на нивоу Б2 која се односи на путовања, а његове модификоване варијанте прилагодити потребама седме лекције на вишем почетном нивоу, у којој се усваја перфекат и тематика текстова је везана за путовање.

Наведени одломци погодни су и за дискусију о ставовима аутора путописа, о његовом виђењу Париза и Сене. На основу анализе садржаја текста посредно се усвајају знања и о српској путописној култури тог времена. ${ }^{15}$

\section{6. ЗАКЉУЧАК}

Да би настава страног језика била што ефикаснија, потребно је комбиновати лингвистичке и књижевне садржаје. Књижевни текст представља добру мотивацију за учење језичких појава. Од њега се полази како би се пронашли примери на којима ће се одређене појаве уочавати и анализирати, на основу којих ће се доносити закључци и стечена знања увежбавати и проширивати. Уметнички доживљаји, садржани у књижевном тексту, чине граматичко градиво конкретнијим, лакшим и применљивијим.

Текст помаже у учењу лексике, посебно специфичних лексичких спојева попут колокација и идиома, и усвајању знања о стилским фигурама. Користан је као полазни материјал за овладавање свим језичким вештинама, нарочито за стварање нових текстова. Учење напамет, пре свега песама и драмских текстова, за резултат има боље владање језиком и јачање комуникативне компетенције, што и јесте примарни циљ савремене наставе страног језика. Успостављање сличности и разлика између J1 и J2

15 „Слично чине и српски путописци: усвајају хаос, виде га, али ипак устројавају у нарацију која почива на јединственој субјективности путника (приповедача, писца). Иако путописи радо говоре о хаосу, његово увођење у само приповедање остаје у равни садржаја, док на плану израза и даље влада поузданост. Хаос се повезује са сумњом, она се тиче пре свега „светског поретка“. Када је реч о сазнајним и сређивачким могућностима књижевности, путопис углавном остаје део традиције реализма и конвенције према којој се пишчев ауторитет темељи на положају његове личности која се на неки начин налази изнад друштва. Ипак, јављају се и одређени видови субјективистичке нарације у којој се изразитије огледа специфична ситуација онога ко приповеда, његов положај у свету који више није подразумеван, већ измештен и оспорен“ (Gvozden 2011: 135). 
додатно мотивише студенте да, упознајући лексичке и граматичке јединице, упознају и дух тог језика. Развија се способност критичког мишљења, усвајају културни обрасци, посебности народа чији се језик учи, али и универзалне вредности. Укључивањем књижевних текстова у курсеве страних језика подстиче се екстензивно читање на вишим нивоима учења.

Јасно је да су користи од књижевног текста у настави страног језика вишеструке. Са естетске стране, пружа ужитак приликом читања и мотивацију за изучавање садржаја и његову дубљу анализу. Поред тога, нуди бројне примере корисне за усвајање знања из лексике и граматике. Речи и изрази се уочавају и уче у контексту, граматичке јединице такође, што је далеко бољи начин учења и увежбавања него на изолованим примерима. Сваки књижевни текст, без обзира на то да ли се ради о прозном, поетском или драмском делу, може пронаћи своје место у настави страног језика, само га је потребно пажљиво одабрати и прилагодити нивоу знања студената и циљевима лекције или тематске целине у оквиру које се користи.

\section{ЛИТЕРАТУРА}

Анђелковић, С. (2011). “Текстови српских песника и драмских писаца од катедре до сцене“, у Српски као страни језик у теорији и пракси II, ур. М. Дешић (Београд: Филолошки факултет): 335-341. [Anđelković, S. (2011). "Tekstovi srpskih pesnika i dramskih pisaca od katedre do scene", u Srpski kao strani jezik u teoriji i praksi II, ur. M. Dešić (Beograd: Filološki fakultet): 335-341.]

Ђоровић, Д. (2011). “Вештине читања и развијања вокабулара за специфичне потребе у настави језика струке на универзитетском нивоу”. Теме 35/3: 819-836. Приступљено 20. 12. 2015. [Đorović, D. (2011). "Veštine čitanja i razvijanja vokabulara za specifične potrebe u nastavi jezika struke na univerzitetskom nivou". Teme 35/3: 819-836. Pristupljeno 20. 12. 2015.] URL: 〈http://teme2.junis.ni.ac.rs/index.php/TEME〉.

Gvozden, V. (2011). "Haos stvari i poredak reči: srpska putopisna kultura 19141940. i modernizacijski procesi". Polja 56/467: 125-135. Pristupljeno 29. 12. 2015. URL: 〈http://polja.rs/wp-content/uploads/2015/12/467-24.pdf〉.

Иванова, И. (2011). "Лингвокултуролошки коментар књижевног дела у настави српског језика и књижевности“, у Српски као страни језик у теорији и пракси II, ур. М. Дешић (Београд: Филолошки факултет): 113-121. [Ivanova, I. (2011). "Lingvokulturološki komentar književnog dela u nastavi srpskog jezika i književnosti“, u Srpski kao strani jezik u teoriji i praksi II, ur. M. Dešić (Beograd: Filološki fakultet): 113-121.] 
Илић, П. (2006). Српски језик и књижевност у наставној теорији и пракси. Нови Сад: Змај. [Илић, П. (2006). Српски језик и књижевност у наставној теорији и пракси. Нови Сад: Змај.]

Marković, J. (2005). "Ekstenzivno čitanje u nastavi stranih jezika". Radovi Filozofskog fakulteta (Pale) 6-7: 491-497. Pristupljeno 20. 12. 2015.

URL: 〈http://www.filozof.org/pdf\%20format/jelena\%20markovic\%2028.pdf〉.

Nation, I.S.P. (2001). "Vocabulary and reading and writing", Learning vocabulary in Another Language. United Kingdom: University Press, Cambridge. 236-285. Приступљено 25. 12. 2015.

URL:«http://ir.nmu.org.ua/bitstream/handle/123456789/127342/1721452a3f1561 f1bd57c2ba30d9ab32.pdf?sequence $=1$ > .

Несторовић, 3. (2011). "Примери примене садржаја из књижевности у настави српског језика као страног”, у Српски као страни језик у теорији и пракси II, ур. М. Дешић (Београд: Филолошки факултет): 207-216. [Nestorović, Z. (2011). "Primeri primene sadržaja iz književnosti u nastavi srpskog jezika kao stranog", u Srpski kao strani jezik u teoriji $i$ praksi II, ur. M. Dešić (Beograd: Filološki fakultet): 207-216.]

Pejić, T., Nigojević, M. (2004). "Obrada bajke u nastavi stranih jezika (primjeri iz nastave talijanskoga i engleskoga jezika)". Strani jezici 33/1-2: 147156. Pristupljeno 25. 12. 2015. URL: https://bib.irb.hr/datoteka/190114. Strani_jezici_2004.pdf .

Петровачки, Љ. (2008). Методичка истраживања у настави српског језика u къижевности. Нови Сад: Филозофски факултет, Одсек за српски језик и лингвистику. [Petrovački, LJ. (2008). Metodička istraživanja u nastavi srpskog jezika i književnosti. Novi Sad: Filozofski fakultet, Odsek za srpski jezik i lingvistiku.]

Петровачки, Љ., Штасни Г. (2008). Методичке апликачије - планирање, програмирање и припремање наставе српског језика и књижевности. Нови Сад: Филозофски факултет, Одсек за српски језик и лингвистику. [Petrovački, LJ., Štasni G. (2008). Metodičke aplikacije - planiranje, programiranje i pripremanje nastave srpskog jezika i književnosti. Novi Sad: Filozofski fakultet, Odsek za srpski jezik i lingvistiku.]

Scrivener, J. (2005). Learning Teaching - A guidebook for English language teachers - Second Edition. Great Britain: Macmillan Publishers Limited. Pristupljeno 28. 12. 2015. URL: 〈https://archive.org/stream/LearningTeaching/Learning-Teaching-by-James-Scrivener\#page/n13/mode/2up .

Суботић, Љ., Бјелаковић, И. (2007). “Центар за српски језик као страни на Филозофском факултету у Новом Саду (искуства и перспективе)”, у Српски као страни језик у теорији и пракси I, ур. М. Дешић (Београд: 
Филолошки факултет): 173-183. [Subotić, LJ., Bjelaković, I. (2007). "Centar za srpski jezik kao strani na Filozofskom fakultetu u Novom Sadu (iskustva i perspektive)", u Srpski kao strani jezik u teoriji i praksi I, ur. M. Dešić (Beograd: Filološki fakultet): 173-183.]

Ur, P. (1997). A Course in Language Teaching: Practice and Theory. United Kingdom: University Press, Cambridge.

Zajednički evropski okvir za žive jezike: učenje, nastava, ocjenjivanje (2003). Podgorica: Ministarstvo prosvjete.

\section{Извори:}

Alanović, M. i dr. (2007). Naučimo srpski (Let’s learn Serbian) 2. Novi Sad: Dnevnik - novine i časopisi.

Антологија српске поезије (2005). Ваљево: Парнас. [Antologija srpske poezije (2005). Valjevo: Parnas.]

Bjelaković, I., Vojnović, J. (2010). Naučimo srpski (Let’s learn Serbian) 1 - treće izdanje. Novi Sad: Filozofski fakultet, Odsek za srpski jezik i lingvistiku, Centar za srpski jezik kao strani.

Дучић, Ј. (1971). “Градови и химере”, у Есеји. Путописи. Нови Сад: Матица српска; Београд: Српска књижевна задруга: 91-237. Приступљено 29. 12. 2015. [Dučić, J. (1971). "Gradovi i himere", u Eseji. Putopisi. Novi Sad: Matica srpska; Beograd: Srpska književna zadruga: 91-237. Pristupljeno 29. 12. 2015.] URL: 〈http://www.slideshare.net/Shejla/jovandui-eseji-gradovi-i-himere-jutra-sa-leutara .

“Тамни вилајет”, у Српске народне бајке (2000). Београд: Креативни центар: 199. Приступљено 30. 12. 2015. [“Tamni vilajet”, u Srpske narodne bajke (2000). Beograd: Kreativni centar: 199. Pristupljeno 30. 12. 2015.]

URL: 〈http://www.childrenslibrary.org/icdl/BookPage?bookid=srpskeb_0038005 $9 \&$ pnum $1=201 \&$ twoPage $=$ false $\&$ route $=$ text $\&$ size $=0 \&$ fullscreen $=$ false $\&$ la ng=Serbian\&ilang=Croatian .

Jelena Perišić

University of Novi Sad

Faculty of Philosophy - doctoral studies of Language and Literature

Novi Sad

jelenaperisic91@hotmail.com 
THE USE OF A LITERARY TEXT IN TEACHING (SERBIAN AS A FOREIGN) LANGUAGE

\section{Summary}

Teaching literature of the target language gives many benefits to any course whose main objective is achieving proficiency in the language itself. Therefore, this paper aims at exploration and discovery of desirable characteristics of literary texts in teaching Serbian as second language and best ways of its implementation. Accordingly, we will emphasize the importance of correlation between teaching language and its literature as well as the importance of the use of literary texts in foreign language teaching. Next, we will present requirements set by Common European Framework of Reference for Languages considering texts used in teaching a foreign language and make a review of the earlier discussion on this topic. Finally, respecting the given criteria, we are going to make a proposition of the texts and their use in teaching Serbian as foreign language at different levels of learning. The first text to be proposed is Tamni vilajet, the short folk tale. The second one is presented by excerpts from the travelogue Gradovi $i$ himere written by Jovan Dučić. Both of the texts are not important only for learning and practicing grammar, vocabulary and stylistics but also for adoption of the cultural pattern as well.

Key words: foreign language teaching, Serbian as a foreign language, literary text, Common European Framework of Reference for Languages.

\section{ПРИЛОГ 1}

\section{Тамни вилајей - народна бајка}

Приповиједа се како је некакав цар, дошавши с војском на крај свијета, пошао у тамни вилајет, гдје се никад ништа не види. Не знајући како ће се натраг вратити, оставе ондје ждребад од кобила да би их кобиле из оне помрчине извеле. Кад су ушли у тамни вилајет и ишли по њему, све су под ногама осјећали некакво оситно камење, и из мрака нешто повиче:

- Ко овога камења понесе кајаће се, а ко не понесе кајаће се!

Гдјекоји помисли:

- Кад ћу се кајати, зашто да га носим?

А гдјекоји:

- Дај барем један да понесем.

Кад се врате из таме на свијет, а то оно све било драго камење. Онда они који нијесу понијели стану се кајати што нијесу, а они што су понијели - што нијесу више.

\section{Додатак (на маргинама):}


вилајет значи: област, покрајина, земља, свет;

оставити ждребад од кобила значи: одвојити ждребад од кобила. Коњ је паметна и осећајна животиња, одлично се сналази на путевима и дању и ноћу, те су људи одувек имали поверења у коња да ће их тачно одвести тамо где треба; вођена љубављу према ждребету, кобила је могла да се врати њему и из тамног вилајета;

драго камење је камење велике лепоте и вредности, а то су дијаманти, рубини, сафири, смарагди. Дивних су боја и тако блистави да се од њих прави накит.

\section{ПРИЛОГ 2}

\section{Јован Дучић: „Градови и химере“6}

\section{А) Писмо из Француске, стр. 115.}

Нешто се данас наједном променило у мојој улици, старој, бедној, анонимној. Била је до сада тесна као тамнички ходник. По њој су месецима лиле црне кише, и смркавало се већ од подне. Јутра се нису познавала по забељеним прозорима, него по нашем очајању од вечног мрака. Али је данас напрасно наишла однекуд река светлости, и младо сунце упалило по плафону читаве пантомиме змајева и широке огњене шуме. По мокрим црним крововима разлетели се голубови од ватре, и запалио се један крупан облак у висини. А кад је наједном зазвонило са неке цркве, гласови звона прошли су небом као велика сребрна једра, хиљадама једно за другим.

Ни у највећем граду, над чијим улицама висе само уска платна неба, пролеће се не да сакрити. Пролеће није овде на стварима колико у очима људи и у покрету жена. Пролеће је, јер јучерашње среће не изгледају више среће; јер је љубав и неверство у ваздуху и води; јер су жене данас лепше него икада пре у животу; и зато што се пробудимо са једним стихом у памети и једним новим женским именом на уснама; и, најзад, што прођемо данас кроз Латински кварт као стари грчки бог кроз златну кишу.

\section{Б) Писмо из Француске, стр. 146-147.}

Хиљаде тесних улица и широких булевара пресецају овај огромни Париз. Али најлепши и највеселији булевар, то је Сена, са зеленилом њене воде, са ватрама које сунце упаљује по њеној површини и са руменим маглама које се вечером дижу из њених камених корита. Ни Темза у Лондону, ни Тибар у Риму, немају оно значење које има Сена у Паризу. Ова река није овде артерија града него главни нерв живота. Нико у енглеском главном граду не одлази нарочито да види Темзу, нити у Риму жури да види Тибар, као ни Дунав у Бечу, ни Спреву у Берлину. Али и онај човек који је јутрос стигао у Париз, пожуриће да види Сену још исто пре подне; а онај који овде стално живи, ићи ће сваки дан да је поново види. По великим булеварима париским, почевши од цркве Свете Магдалене, тумара обичан свет који 
продаје своју робу или своју сујету, и жури свет који то купује; али само поред Сене иду они који посматрају, размишљају, уче, и проживљавају Париз у његовој неодољивој суштини и несравњивој лепоти. Онамо је Париз дневни и пролазни, а овде је Париз хиљадугодишњи и вечни. На другим су местима господске палате, сјајни магазини и радосни кабарети, а овде су краљеви дворови и споменици науке и вере, и то још од средњег века. Онамо шуми живот и тече оргија младости, а овде мирује прошлост и почива велика традиција славе.

Примљено: 29. 3. 2016.

Прихваћено: 21. 4. 2016. 